\title{
Performance Evaluation of Contract Employees Using the Best-Worst and Simple Additive Weighting Methods
}

\author{
Rendra Gustriansyah ${ }^{1}$, Juhaini Alie ${ }^{2}$, Nazori Suhandi ${ }^{3}$ \\ ${ }^{1,2,3}$ Universitas Indo Global Mandiri, Palembang, Indonesia \\ ${ }^{1}$ rendra@uigm.ac.id, ${ }^{2}$ juhaini@uigm.ac.id, ${ }^{3}$ nazori@uigm.ac.id
}

\begin{abstract}
All companies need qualified employees to ensure the continuity and progress of the company. Therefore, some companies are very selective in evaluating employee performance based on the criteria set by the company. However, because of the many criteria used in the assessment, a large number of contract employees to be evaluated, and the evaluation that must be proportional, the Human Resources department has difficulty evaluating the performance of contract employees. Therefore, this study aimed to develop a system for evaluating the performance of contract employees by integrating the Best-Worst (BW) and Simple Additive Weight (SAW) methods. The BW method is used to determine the weight of each criterion related to the performance appraisal of contract employees, and the SAW method is used to evaluate the performance of contract employees. The results showed that the system developed can provide a more proportional evaluation. So, this study contributes as a recommendation system for $H R$ managers in determining eligible contract employees to have their work contracts extended based on criteria determined by the company.
\end{abstract}

Keywords: Best-Worst method, contract employees, performance evaluation, Simple Additive Weighting

\section{INTRODUCTION}

Human resources (HR) is the most important element in a company because HR will control other resources such as capital and technology [1]. Therefore, employees have a very strategic role as the prime mover in determining the smooth running of activities within a company.

According to Law of the Republic of Indonesia, Number 11 of 2020 concerning Job Creation, a contract employee/work agreement is an employee who works for an agency based on a work agreement for a certain time that can only be made for certain jobs which according to the type and nature of work activities will be completed within certain. In the work contract, there is a cause for contract extension which aims to retain potential employees for the progress of the company.

All companies need qualified employees to ensure the survival and progress of the company so that some companies are very selective in evaluating the performance of contract employees based on the criteria set by the company. However, some companies have difficulty evaluating the performance of their employees because of the many criteria used in the assessment, the number of contract employees proposed in a period, and the assessment that must be objective and consistent so that the company's HR department has difficulty evaluating the performance of the right contract employees for the extension of the work contract.

Therefore, this study aims to build a contract employee performance evaluation system by integrating the Best-Worst (BW) and Simple Additive Weight (SAW) methods. The BW method was selected because the number of pairwise comparisons is less than the other multi-criteria decision-making (MCDM) methods [2] and the SAW method was selected because of the simplicity of the method stages in obtaining the best alternative [3].

There are several MCDM methods that can be used to calculate the criteria weight and alternative ranking, including BW [4-5], AHP [6], FAHP [7], TOPSIS [8], VIKOR [9], ANP [10], SAW [11-16], PROMETHEE [17], MAUT [18]. In this study, one of the MCDM methods, namely the BW method, will be used to determine the weight of each criterion for evaluating the performance of contract employees.

Based on the literature obtained from Google Scholar, there are 24 studies have discussed decision support systems or recommendation systems related to the determination of contract employees; 7 studies using the TOPSIS method [19-25], 6 studies using the SAW method [11-16], 4 studies using the SMART method [2629], 2 studies using the Rating Scale method [30-31], and the rest of the study used AHP [6], ELECTRE [32], VIKOR [9], PROMETHEE [17], and MAUT [18] 
methods. There were no previous studies that used the BW method for the efficiency of the number of pairwise comparisons in obtaining the weight of each criterion and integrating it with other MCDM methods so that the evaluation results are more optimal and proportional.

This research is expected to increase the productivity of the analysis and make the HR manager time-efficient in making decisions about employees who are eligible to extend their work contracts according to the criteria set by the company.

\section{METHOD}

\section{A. Research Design}

This research was designed in six phases as illustrated in Fig. 1. Phase 1 is the phase of identifying criteria and alternatives of contract employees, then calculating the optimal weight of each criterion using the BW method. After the competency value of each contract employee is obtained from the head of the HR department of a bottled drinking water production and distribution company in the city of Palembang, an evaluation of the performance of contract employees will be carried out using the SAW method so that a contract employee rank will be obtained which will be recommended for the extension of the work contract period. This contract employee performance evaluation system will be designed using UML [33] and is expected to be a tool for recommending contract employees who are eligible for the extension of their work contracts [34].

\section{B. Best-Worst Method}

The Best-Worst (BW) method is one of the multicriteria decision-making (MCDM) methods introduced by Jafar Rezaei in 2015. The BW method can be used to obtain the optimal weight of each decision criterion by comparing the best criteria against other criteria (Best to-Others) and all other criteria against the worst criteria (Others-to-Worst) through a simple linear equation model [35].
The BW method that will be used to obtain the optimal weight for each criterion consists of five stages as follows [36]:

- Stage 1 : Identify the $c_{1}, c_{2}, \ldots, c_{n}$ criteria involved in making the decision.

- Stage 2 : Determine the best (most influential) criterion and the worst (least influential) criterion from the group of criteria.

- Stage 3 : Comparing the best criteria against all other criteria (B2O). The comparison value is expressed as a score between 1 and 9 where a score of 1 indicates the same level of influence as the selected criteria and a score of 9 means an extreme level of influence. The resulting Best-toOthers vector is $\boldsymbol{C}_{B}=\left(c_{B 1}, c_{B 2}, \ldots ., C_{B n}\right)$, where $c_{B j}$ is the priority value of the best criterion $c_{B}$ against other criteria $c_{j}$.

- Stage 4 : Comparing all the other criteria against the worst criteria $(\mathrm{O} 2 \mathrm{~W})$ and expressing using a score between 1 and 9. A score of 1 means that the selected criterion has the same value which does not affect the worst criterion and a score of 9 means that the selected criterion is very far more influential so that the resulting $\mathrm{O} 2 \mathrm{~W}$ vector is $\boldsymbol{C}_{W}$ $=\left(c_{1 W}, c_{2 W}, \ldots, c_{n W}\right)^{T}$, where $c_{j W}$ is the priority value of the criteria $c_{j}$ against the worst criterion $c_{W}$.

- Stage 5 : Calculate the optimal weights of $w_{1}{ }^{*}$, $w_{2}{ }^{*}, \ldots, w_{n}{ }^{*}$ for each criterion. The optimal weight for each criterion is calculated using the minmax model as in (1) where the maximum absolute value for all $j$ of the set $\left\{\left|w_{B}-c_{B j} w_{j}\right|,\left|w_{j}-c_{j w} w_{w}\right|\right\}$ is minimized.

$$
\min \max _{j}\left\{\left|\frac{w_{B}}{w_{j}}-c_{B j}\right|,\left|\frac{w_{j}}{w_{w}}-c_{j w}\right|\right\}
$$

Eq. (1) can be formulated into a linear equation model as in (2).

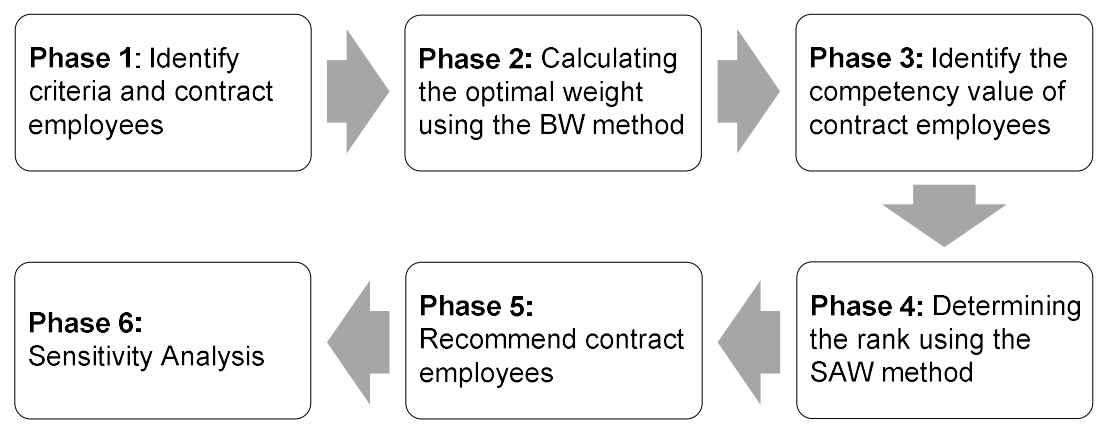

Fig. 1 Six phases of research 


$$
\begin{aligned}
& \qquad \begin{array}{c}
\min \xi \\
\text { s.t. }
\end{array} \\
& \left|\frac{w_{B}}{w_{j}}-c_{B j}\right| \leq \xi^{*}, \text { for all } j \\
& \left|\frac{w_{j}}{w_{w}}-c_{j w}\right| \leq \xi^{*}, \text { for all } j \\
& \sum_{j} w_{j}=1 \\
& w_{j} \geq 0, \text { for all } j \\
& \text { where } j=1,2, \ldots, n
\end{aligned}
$$

The optimal weights of $w_{1}{ }^{*}, w_{2}{ }^{*}, \ldots, w_{n}{ }^{*}$ for each criterion and the $\xi^{*}$ value can be obtained by solving Equation (2). The consistency degree of pairwise comparisons will be determined by calculating the consistency ratio (CR) using (3):

$$
C R=\frac{\xi^{*}}{C I}
$$

where $C I$ (consistency index) is the maximum $\xi$ value for $c_{B W}$ as shown in Table I, $\xi^{*}$ is the consistency indicator, and $C R \in[0,1]$. The more consistent the pairwise comparison, the closer the $C R$ value will be to zero, while the $C R$ value is closer to one indicates that the pairwise comparison is less consistent [37].

\section{Simple Additive Weighting Method}

The Simple Additive Weighting (SAW) method is one of the MCDM methods first proposed by Churchman and Ackoff to overcome selection problems [38]. The SAW method has a simple concept, easy to understand, efficient calculation, and can measure the relative performance of a decision [39]. [40]:

The stages of the SAW method are as follows [3],

- Stage 1: Identifying alternatives $\boldsymbol{A}_{i}$. In this study, the alternative $\boldsymbol{A}_{i}$ is a contract employee who will be evaluated for the extension of his work contract. Then determine the matrix elements $A_{i}$ for each criterion $\boldsymbol{C}_{j}$. The $\boldsymbol{A}_{i j}$ element comes from the competency value of each contract employee obtained directly from the head of the HR department.

- Stage 2: Normalize the $A_{i j}$ matrix to a $r_{i j}$ matrix based on (4).

$$
\boldsymbol{r}_{i j}=\left\{\begin{array}{l}
\frac{A_{i j}}{A_{i j}^{\max }}, j \in \text { "the set of positive criteria" } \\
\frac{A_{i j}^{\text {min }}}{A_{i j}}, j \in \text { "the set of negative criteria" }
\end{array}\right.
$$

where $r_{i j}$ is the normalized matrix, $\boldsymbol{A}_{i j}$ is the decision matrix, $\max \boldsymbol{A}_{i j}$ is the largest value of each criterion $\boldsymbol{C}_{j}$, $\min \boldsymbol{A}_{i j}$ is the smallest value of each $\boldsymbol{C}_{j}$ criterion, positive criteria if the largest value $A_{j}$ is the most important value, and negative criteria if the lowest value $A_{j}$, the most important value.

- Stage 3: Identify the weight $\boldsymbol{W}_{j}$ for each criterion $\boldsymbol{C}_{j}$. In this study, the weight of $\boldsymbol{W}_{j}$ is obtained from the optimal weight of the BW method.

- Stage 4: Calculating the priority value for the alternative value $\boldsymbol{V}_{i}$ based on (5).

$$
\boldsymbol{V}_{i}=\sum_{j=1}^{n} \boldsymbol{W}_{j} \boldsymbol{r}_{i j}
$$

where $\boldsymbol{V}_{i}$ is the rank for each alternative $\boldsymbol{A}_{i}$ and $\boldsymbol{W}_{j}$ is the weight matrix for each criterion, $\boldsymbol{W}_{j} \in(0,1)$. The highest $\boldsymbol{V}_{i}$ value is the most recommended alternative from all alternatives [38].

\section{RESULTS AND DISCUSSION}

\section{A. Calculating The Optimal Weight Using The BW Method}

1) Stage 1: Identify the criteria. This study uses 14 criteria for the performance appraisal of contract employees obtained from companies producing and distributing bottled drinking water in the city of Palembang, consisting of; $\mathrm{K}_{1}$ : loyalty, $\mathrm{K}_{2}$ : discipline, $\mathrm{K}_{3}$ : hard work, $\mathrm{K}_{4}$ : thoroughness, $\mathrm{K}_{5}$ : tenacity, $\mathrm{K}_{6}$ : speed of work, $\mathrm{K}_{7}$ : quality of work, $\mathrm{K}_{8}$ : cooperation, $\mathrm{K}_{9}$ : conveying ideas, $\mathrm{K}_{10}$ : emotional stability, $\mathrm{K}_{11}$ : responsibility, $\mathrm{K}_{12}$ : initiative, $\mathrm{K}_{13}$ : adaptation, $\mathrm{K}_{14}$ : communication.

2) Stage 2: Determine the best and worst criteria. The head of the company's HR department determines that the most influential (best) criterion in the performance evaluation process for contract employees is discipline. Meanwhile, the worst criterion is tenacity.

TABLE I

CONSISTENCY INDEX [35]

\begin{tabular}{lccccccccc}
\hline $\boldsymbol{c}_{\boldsymbol{B} \boldsymbol{W}}$ & 1 & 2 & 3 & 4 & 5 & 6 & 7 & 8 & 9 \\
\hline $\boldsymbol{C I}(\max \boldsymbol{\xi})$ & 0.00 & 0.44 & 1.00 & 1.63 & 2.30 & 3.00 & 3.73 & 4.47 & 5.23 \\
\hline
\end{tabular}


3) Stage 3: Comparing the best criteria against all other criteria. The head of the HR department determines the priority level between the best criteria against all other criteria (B2O) with a score interval of 1 to 9 as shown in Table II.

4) Stage 4: Compare all the other criteria against the worst criteria. Stage 4 is identical to stage 3 where the head of the HR department determines the priority level of all other criteria against the worst criteria $(\mathrm{O} 2 \mathrm{~W})$ with a score interval of 1 to 9 as can be seen in Table III.
5) Stage 5: Calculating the optimal weight for each criterion. The optimal weight for each criterion listed in Table IV is obtained by processing the data in Tables II and III using (2). Table IV shows that the consistency indicator value $\xi^{*}$ is 0.7771 . Because $\mathrm{c}_{\mathrm{BW}}=4$, the CI value is 1.63 , so that the $C R$ value can be obtained using (3) of 0.4768 . Because the CR value is close to zero, the pairwise comparison has a high consistency.

TABLE II

THE BEST-TO-OTHERS (B2O) VECTOR

\begin{tabular}{lcccccccccccccc}
\hline Criteria & $\mathrm{K}_{1}$ & $\mathrm{~K}_{2}$ & $\mathrm{~K}_{3}$ & $\mathrm{~K}_{4}$ & $\mathrm{~K}_{5}$ & $\mathrm{~K}_{6}$ & $\mathrm{~K}_{7}$ & $\mathrm{~K}_{8}$ & $\mathrm{~K}_{9}$ & $\mathrm{~K}_{10}$ & $\mathrm{~K}_{11}$ & $\mathrm{~K}_{12}$ & $\mathrm{~K}_{13}$ & $\mathrm{~K}_{14}$ \\
\hline Best: Discipline $\left(\mathrm{K}_{2}\right)$ & 1 & 1 & 1 & 2 & 4 & 1 & 1 & 2 & 2 & 2 & 1 & 2 & 2 & 1 \\
\hline
\end{tabular}

TABLE III

OTHERS-TO-WORST (O2W) VECTOR

\begin{tabular}{cc}
\hline Criteria & Worst: Tenacity $\left(\mathrm{K}_{5}\right)$ \\
\hline $\mathrm{K}_{1}$ & 3 \\
$\mathrm{~K}_{2}$ & 4 \\
$\mathrm{~K}_{3}$ & 4 \\
$\mathrm{~K}_{4}$ & 3 \\
$\mathrm{~K}_{5}$ & 1 \\
$\mathrm{~K}_{6}$ & 3 \\
$\mathrm{~K}_{7}$ & 4 \\
\hline
\end{tabular}

\begin{tabular}{cc}
\hline Criteria & Worst: Tenacity $\left(\mathrm{K}_{5}\right)$ \\
\hline $\mathrm{K}_{8}$ & 3 \\
$\mathrm{~K}_{9}$ & 2 \\
$\mathrm{~K}_{10}$ & 2 \\
$\mathrm{~K}_{11}$ & 3 \\
$\mathrm{~K}_{12}$ & 3 \\
$\mathrm{~K}_{13}$ & 3 \\
$\mathrm{~K}_{14}$ & 3 \\
\hline
\end{tabular}

TABLE IV

THE OPTIMAL WEIGHT $w_{j}$ FOR EACH CRITERION

\begin{tabular}{|c|c|}
\hline Criteria & Weight \\
\hline $\mathrm{K}_{1}{ }^{*}$ Loyalty & 0.0877 \\
\hline $\mathrm{K}_{2}{ }^{*}$ Discipline & 0.0877 \\
\hline $\mathrm{K}_{3}{ }^{*}$ Hard work & 0.0877 \\
\hline $\mathrm{K}_{4}{ }^{*}$ Thoroughness & 0.0614 \\
\hline $\mathrm{K}_{5}{ }^{*}$ Tenacity & 0.0175 \\
\hline $\mathrm{K}_{6}^{*}$ Speed of work & 0.0877 \\
\hline $\mathrm{K}_{7}{ }^{*}$ Quality of work & 0.0877 \\
\hline $\mathrm{K}_{8}{ }^{*}$ Cooperation & 0.0614 \\
\hline $\mathrm{K}_{9}{ }^{*}$ Conveying idea & 0.0614 \\
\hline $\mathrm{K}_{10}{ }^{*} \begin{array}{l}\text { Emotional } \\
\text { stability }\end{array}$ & 0.0614 \\
\hline $\mathrm{K}_{11}{ }^{*}$ Responsibility & 0.0877 \\
\hline $\mathrm{K}_{12}{ }^{*}$ Initiative & 0.0614 \\
\hline $\mathrm{K}_{13}{ }^{*}$ Adaptation & 0.0614 \\
\hline $\mathrm{K}_{14}{ }^{*}$ Communication & 0.0877 \\
\hline$\xi^{*}$ & 0.7771 \\
\hline
\end{tabular}

B. Evaluating The Performance of Contract Employees Using The SAW Method

This contract employee competency data is assessed directly by the head of the company's HR department. Table $\mathrm{V}$ is an alternative $A_{i}$ or a list of employees who will be evaluated for their contract extension along with the competency scores for each criterion. The alternative matrix $A_{i}$ that has been normalized $\left(r_{i j}\right)$ using (4) is shown in Table VI.

The priority value $\boldsymbol{V}_{i}$ for each alternative $\boldsymbol{A}_{i}$ listed in Table VII is obtained from the multiplication of the optimal weight $\boldsymbol{w}_{\boldsymbol{j}}$ from Table IV with the normalized matrix $r_{i j}$ from Table VI based on (5).

If the value of priority $\boldsymbol{V}_{i}$ for each alternative $\boldsymbol{A}_{i}$ is added up, the performance rank of contract employees can be seen in Fig. 3. Meanwhile, Fig. 4 shows a graph of the performance ranking of contract employees without involving the weight of the criteria proportionally (Table V). 
TABLE V

COMPETENCY SCORES OF CONTRACT EMPLOYEES

\begin{tabular}{lccccccccccc}
\hline Criteria & $\mathbf{A}_{\mathbf{1}}$ & $\mathbf{A}_{\mathbf{2}}$ & $\mathbf{A}_{\mathbf{3}}$ & $\mathbf{A}_{\mathbf{4}}$ & $\mathbf{A}_{\mathbf{5}}$ & $\mathbf{A}_{\mathbf{6}}$ & $\mathbf{A}_{\mathbf{7}}$ & $\mathbf{A}_{\mathbf{8}}$ & $\mathbf{A}_{\mathbf{9}}$ & $\mathbf{A}_{\mathbf{1 0}}$ & $\overline{\mathbf{A}}$ \\
\hline $\mathrm{K}_{1}$ & 85 & 80 & 85 & 78 & 85 & 85 & 85 & 85 & 85 & 80 & 82,71 \\
$\mathrm{~K}_{2}$ & 80 & 79 & 79 & 78 & 85 & 80 & 84 & 85 & 82 & 80 & 79,14 \\
$\mathrm{~K}_{3}$ & 85 & 80 & 80 & 80 & 80 & 80 & 80 & 80 & 80 & 80 & 81,93 \\
$\mathrm{~K}_{4}$ & 80 & 80 & 83 & 80 & 80 & 80 & 85 & 84 & 84 & 80 & 79,71 \\
$\mathrm{~K}_{5}$ & 80 & 80 & 80 & 80 & 85 & 80 & 80 & 85 & 80 & 80 & 81,57 \\
$\mathrm{~K}_{6}$ & 85 & 80 & 80 & 80 & 80 & 80 & 80 & 80 & 80 & 80 & 80,93 \\
$\mathrm{~K}_{7}$ & 83 & 80 & 82 & 82 & 81 & 84 & 84 & 82 & 83 & 80 & 81,93 \\
$\mathrm{~K}_{8}$ & 84 & 79 & 84 & 80 & 82 & 84 & 84 & 84 & 84 & 80 & 82,14 \\
$\mathrm{~K}_{9}$ & 87 & 80 & 80 & 80 & 85 & 80 & 85 & 80 & 80 & 80 & 81,36 \\
$\mathrm{~K}_{10}$ & 80 & 70 & 85 & 78 & 79 & 80 & 80 & 80 & 80 & 75 & 79,64 \\
$\mathrm{~K}_{11}$ & 80 & 80 & 80 & 80 & 80 & 80 & 80 & 80 & 80 & 80 & 82,71 \\
$\mathrm{~K}_{12}$ & 84 & 80 & 85 & 80 & 80 & 80 & 80 & 85 & 80 & 80 & 79,14 \\
$\mathrm{~K}_{13}$ & 80 & 80 & 80 & 80 & 80 & 80 & 80 & 80 & 80 & 80 & 81,93 \\
$\mathrm{~K}_{14}$ & 85 & 80 & 84 & 80 & 80 & 80 & 80 & 80 & 81 & 80 & 79,71 \\
\hline
\end{tabular}

Fig. 2 demonstrates that seven contract employees, namely $A_{1}, A_{7}, A_{8}, A_{3}, A_{9}, A_{5}$, and $A_{6}$ have good performance so that they deserve to be recommended to extend their work contracts, while three contract employees namely $\mathrm{A}_{4}, \mathrm{~A}_{10}$, and $\mathrm{A}_{2}$ are not recommended. The results of this recommendation are almost the same as the results of the recommendations without considering the weight of each criterion proportionally (all criterion weights are considered to be the same) where there are seven recommended contract employees, namely $\mathrm{A}_{1}, \mathrm{~A}_{8}, \mathrm{~A}_{7}, \mathrm{~A}_{3}, \mathrm{~A}_{5}, \mathrm{~A}_{9}$, and $\mathrm{A}_{6}$. While three contract employees were not recommended, namely $\mathrm{A}_{4}$, $\mathrm{A}_{10}$, and $\mathrm{A}_{2}$.

TABLE VI

THE NORMALIZATION MATRIX $r_{i j}$ FOR EACH CRITERION

\begin{tabular}{ccccccccccc}
\hline $\begin{array}{c}\text { Crite } \\
\text { ria }\end{array}$ & $\mathbf{A}_{\mathbf{1}}$ & $\mathbf{A}_{\mathbf{2}}$ & $\mathbf{A}_{3}$ & $\mathbf{A}_{4}$ & $\mathbf{A}_{5}$ & $\mathbf{A}_{6}$ & $\mathbf{A}_{7}$ & $\mathbf{A}_{8}$ & $\mathbf{A}_{9}$ & $\mathbf{A}_{10}$ \\
\hline $\mathrm{K}_{1}$ & 1.00 & 0.94 & 1.00 & 0.92 & 1.00 & 1.00 & 1.00 & 1.00 & 1.00 & 0.94 \\
$\mathrm{~K}_{2}$ & 0.94 & 0.93 & 0.93 & 0.92 & 1.00 & 0.94 & 0.99 & 1.00 & 0.96 & 0.94 \\
$\mathrm{~K}_{3}$ & 1.00 & 0.94 & 0.94 & 0.94 & 0.94 & 0.94 & 0.94 & 0.94 & 0.94 & 0.94 \\
$\mathrm{~K}_{4}$ & 0.94 & 0.94 & 0.98 & 0.94 & 0.94 & 0.94 & 1.00 & 0.99 & 0.99 & 0.94 \\
$\mathrm{~K}_{5}$ & 0.94 & 0.94 & 0.94 & 0.94 & 1.00 & 0.94 & 0.94 & 1.00 & 0.94 & 0.94 \\
$\mathrm{~K}_{6}$ & 1.00 & 0.94 & 0.94 & 0.94 & 0.94 & 0.94 & 0.94 & 0.94 & 0.94 & 0.94 \\
$\mathrm{~K}_{7}$ & 0.99 & 0.95 & 0.98 & 0.98 & 0.96 & 1.00 & 1.00 & 0.98 & 0.99 & 0.95 \\
$\mathrm{~K}_{8}$ & 1.00 & 0.94 & 1.00 & 0.95 & 0.98 & 1.00 & 1.00 & 1.00 & 1.00 & 0.95 \\
$\mathrm{~K}_{9}$ & 1.00 & 0.92 & 0.92 & 0.92 & 0.98 & 0.92 & 0.98 & 0.92 & 0.92 & 0.92 \\
$\mathrm{~K}_{10}$ & 0.94 & 0.82 & 1.00 & 0.92 & 0.93 & 0.94 & 0.94 & 0.94 & 0.94 & 0.88 \\
$\mathrm{~K}_{11}$ & 1.00 & 1.00 & 1.00 & 1.00 & 1.00 & 1.00 & 1.00 & 1.00 & 1.00 & 1.00 \\
$\mathrm{~K}_{12}$ & 1.01 & 1.06 & 1.00 & 1.06 & 1.06 & 1.06 & 1.06 & 1.00 & 1.06 & 1.06 \\
$\mathrm{~K}_{13}$ & 1.00 & 1.00 & 1.00 & 1.00 & 1.00 & 1.00 & 1.00 & 1.00 & 1.00 & 1.00 \\
$\mathrm{~K}_{14}$ & 1.00 & 1.06 & 1.01 & 1.06 & 1.06 & 1.06 & 1.06 & 1.06 & 1.05 & 1.06 \\
\hline
\end{tabular}

TABLE VII

MATRIX OF PRIORITY $\boldsymbol{V}_{i}$ FOR EACH ALTERNATIVE $\boldsymbol{A}_{i}$

\begin{tabular}{|c|c|c|c|c|c|c|c|c|c|c|}
\hline Criteria & $\mathbf{A}_{1}$ & $\mathbf{A}_{2}$ & $\mathbf{A}_{3}$ & $\mathbf{A}_{4}$ & A5 & $\mathbf{A}_{6}$ & $\mathbf{A}_{7}$ & A8 & A9 & $\mathbf{A}_{10}$ \\
\hline $\mathrm{K}_{1}$ & 0.088 & 0.083 & 0.088 & 0.080 & 0.088 & 0.088 & 0.088 & 0.088 & 0.088 & 0.083 \\
\hline $\mathrm{K}_{2}$ & 0.083 & 0.082 & 0.082 & 0.080 & 0.088 & 0.083 & 0.087 & 0.088 & 0.085 & 0.083 \\
\hline $\mathrm{K}_{3}$ & 0.088 & 0.083 & 0.083 & 0.083 & 0.083 & 0.083 & 0.083 & 0.083 & 0.083 & 0.083 \\
\hline $\mathrm{K}_{4}$ & 0.058 & 0.058 & 0.060 & 0.058 & 0.058 & 0.058 & 0.061 & 0.061 & 0.061 & 0.058 \\
\hline $\mathrm{K}_{5}$ & 0.017 & 0.017 & 0.017 & 0.017 & 0.018 & 0.017 & 0.017 & 0.018 & 0.017 & 0.017 \\
\hline $\mathrm{K}_{6}$ & 0.088 & 0.083 & 0.083 & 0.083 & 0.083 & 0.083 & 0.083 & 0.083 & 0.083 & 0.083 \\
\hline $\mathrm{K}_{7}$ & 0.087 & 0.084 & 0.086 & 0.086 & 0.085 & 0.088 & 0.088 & 0.086 & 0.087 & 0.084 \\
\hline $\mathrm{K}_{8}$ & 0.061 & 0.058 & 0.061 & 0.058 & 0.060 & 0.061 & 0.061 & 0.061 & 0.061 & 0.058 \\
\hline $\mathrm{K}_{9}$ & 0.061 & 0.056 & 0.056 & 0.056 & 0.060 & 0.056 & 0.060 & 0.056 & 0.056 & 0.056 \\
\hline $\mathrm{K}_{10}$ & 0.058 & 0.051 & 0.061 & 0.056 & 0.057 & 0.058 & 0.058 & 0.058 & 0.058 & 0.054 \\
\hline $\mathrm{K}_{11}$ & 0.088 & 0.088 & 0.088 & 0.088 & 0.088 & 0.088 & 0.088 & 0.088 & 0.088 & 0.088 \\
\hline $\mathrm{K}_{12}$ & 0.061 & 0.058 & 0.061 & 0.058 & 0.058 & 0.058 & 0.058 & 0.061 & 0.058 & 0.058 \\
\hline $\mathrm{K}_{13}$ & 0.061 & 0.061 & 0.061 & 0.061 & 0.061 & 0.061 & 0.061 & 0.061 & 0.061 & 0.061 \\
\hline $\mathrm{K}_{14}$ & 0.088 & 0.083 & 0.087 & 0.083 & 0.083 & 0.083 & 0.083 & 0.083 & 0.084 & 0.083 \\
\hline$\Sigma$ & 0.985 & 0.941 & 0.973 & 0.947 & 0.967 & 0.963 & 0.974 & 0.973 & 0.967 & 0.947 \\
\hline Rank & 1 & 10 & 4 & 8 & 6 & 7 & 2 & 3 & 5 & 9 \\
\hline
\end{tabular}




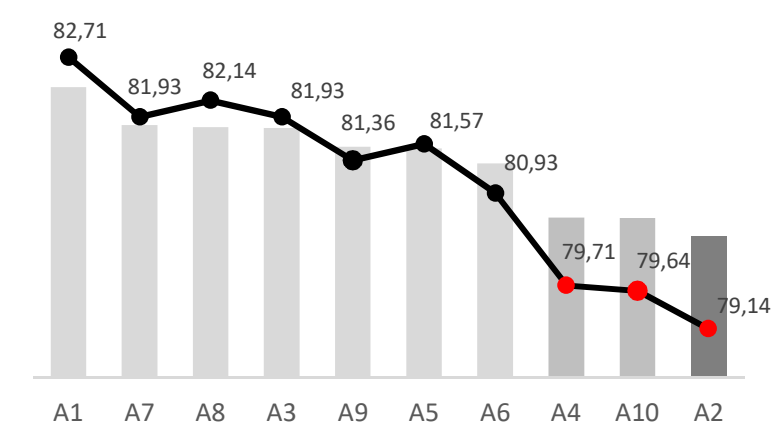

Fig. 2 Performance rating of contract employees with and without considering the weight of each criterion

\section{Sensitivity Analysis}

In this study, the ratings of contract employees were examined by sensitivity analysis. The sensitivity analysis applied to the SAW method considers the importance of each criterion of $0.1,0.3$, and 0.5 individually. Fig. 3 shows the sensitivity analysis for the first criterion $\left(\mathrm{K}_{1}\right)$, and the rest are presented in Tables VIII through XII.

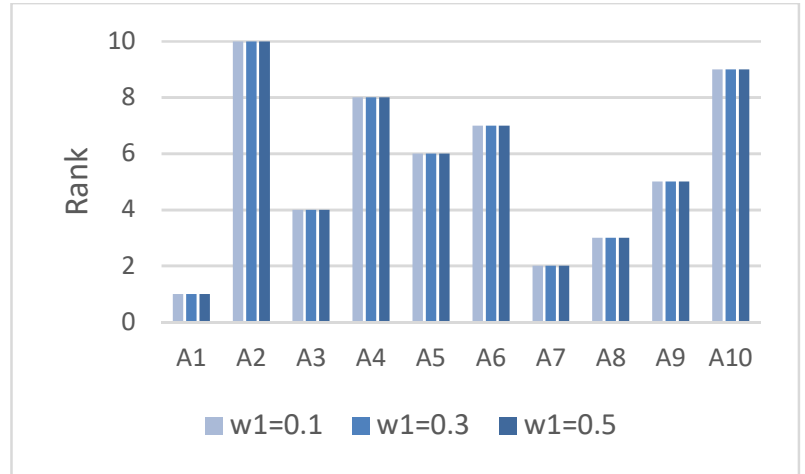

Fig. 3 The sensitivity analysis for criterion 1

In total, forty-two scenarios are analyzed. However, as shown in Tables 8 to 12 , the ranking of the alternatives did not change, namely $\mathrm{A}_{1}-\mathrm{A}_{7}-\mathrm{A}_{8}-\mathrm{A}_{3}-\mathrm{A}_{9}-\mathrm{A}_{5}-\mathrm{A}_{6}-\mathrm{A}_{4}-\mathrm{A}_{10}-$ $\mathrm{A}_{2}$ for the $100 \%$ scenario. Considering all the scenarios, alternative $A_{1}$ seems to have superiority over the other. In contrast, candidates $\mathrm{A}_{2}, \mathrm{~A}_{10}$, and $\mathrm{A}_{4}$ are inferior alternatives. However, the final decision on the employee contract extension is under the control of the $\mathrm{HR}$ manager that refers to the number of $\mathrm{HR}$ needs of the company.

TABLE VIII

SENSITIVITY ANALYSIS WITH RESPECT TO CRITERION 1-3

\begin{tabular}{cccccccccc}
\hline & \multicolumn{3}{c}{$\mathbf{K}_{\mathbf{1}}$} & \multicolumn{3}{c}{$\mathbf{K}_{\mathbf{2}}$} & \multicolumn{3}{c}{$\mathbf{K}_{\mathbf{3}}$} \\
\hline Alternative & $\mathrm{w}_{1}=0.1$ & $\mathrm{w}_{1}=0.3$ & $\mathrm{w}_{1}=0.5$ & $\mathrm{w}_{2}=0.1$ & $\mathrm{w}_{2}=0.3$ & $\mathrm{w}_{2}=0.5$ & $\mathrm{w}_{3}=0.1$ & $\mathrm{w}_{3}=0.3$ & $\mathrm{w}_{3}=0.5$ \\
\hline $\mathrm{A} 1$ & 0.9936 & 1.0111 & 1.0287 & 0.9936 & 1.0111 & 1.0287 & 0.9936 & 1.0111 & 1.0287 \\
$\mathrm{~A} 2$ & 0.9501 & 0.9676 & 0.9852 & 0.9501 & 0.9676 & 0.9852 & 0.9501 & 0.9676 & 0.9852 \\
$\mathrm{~A} 3$ & 0.9817 & 0.9993 & 1.0168 & 0.9817 & 0.9993 & 1.0168 & 0.9817 & 0.9993 & 1.0168 \\
$\mathrm{~A} 4$ & 0.9556 & 0.9731 & 0.9907 & 0.9556 & 0.9731 & 0.9907 & 0.9556 & 0.9731 & 0.9907 \\
$\mathrm{~A} 5$ & 0.9757 & 0.9933 & 1.0108 & 0.9757 & 0.9933 & 1.0108 & 0.9757 & 0.9933 & 1.0108 \\
$\mathrm{~A} 6$ & 0.9713 & 0.9889 & 1.0064 & 0.9713 & 0.9889 & 1.0064 & 0.9713 & 0.9889 & 1.0064 \\
$\mathrm{~A} 7$ & 0.9826 & 1.0001 & 1.0177 & 0.9826 & 1.0001 & 1.0177 & 0.9826 & 1.0001 & 1.0177 \\
$\mathrm{~A} 8$ & 0.9819 & 0.9995 & 1.0170 & 0.9819 & 0.9995 & 1.0170 & 0.9819 & 0.9995 & 1.0170 \\
$\mathrm{~A} 9$ & 0.9763 & 0.9938 & 1.0114 & 0.9763 & 0.9938 & 1.0114 & 0.9763 & 0.9938 & 1.0114 \\
$\mathrm{~A} 10$ & 0.9555 & 0.9730 & 0.9905 & 0.9555 & 0.9730 & 0.9905 & 0.9555 & 0.9730 & 0.9905 \\
\hline
\end{tabular}

TABLE IX

SENSITIVITY ANALYSIS WITH RESPECT TO CRITERION 4-6

\begin{tabular}{cccccccccc}
\hline & \multicolumn{3}{c}{$\mathbf{K}_{\mathbf{4}}$} & \multicolumn{3}{c}{$\mathbf{K}_{\mathbf{5}}$} & \multicolumn{3}{c}{$\mathbf{K}_{\mathbf{6}}$} \\
\hline Alternative & $\mathrm{W}_{4}=0.1$ & $\mathrm{w}_{4}=0.3$ & $\mathrm{w}_{4}=0.5$ & $\mathrm{w}_{5}=0.1$ & $\mathrm{w}_{5}=0.3$ & $\mathrm{w}_{5}=0.5$ & $\mathrm{w}_{6}=0.1$ & $\mathrm{w}_{6}=0.3$ & $\mathrm{w}_{6}=0.5$ \\
\hline $\mathrm{A} 1$ & 0.9910 & 1.0032 & 1.0155 & 0.9866 & 0.9901 & 0.9936 & 0.9936 & 1.0111 & 1.0287 \\
$\mathrm{~A} 2$ & 0.9474 & 0.9597 & 0.9720 & 0.9431 & 0.9466 & 0.9501 & 0.9501 & 0.9676 & 0.9852 \\
$\mathrm{~A} 3$ & 0.9791 & 0.9914 & 1.0037 & 0.9747 & 0.9782 & 0.9817 & 0.9817 & 0.9993 & 1.0168 \\
$\mathrm{~A} 4$ & 0.9529 & 0.9652 & 0.9775 & 0.9486 & 0.9521 & 0.9556 & 0.9556 & 0.9731 & 0.9907 \\
$\mathrm{~A} 5$ & 0.9731 & 0.9854 & 0.9977 & 0.9687 & 0.9722 & 0.9757 & 0.9757 & 0.9933 & 1.0108 \\
$\mathrm{~A} 6$ & 0.9687 & 0.9810 & 0.9933 & 0.9643 & 0.9678 & 0.9713 & 0.9713 & 0.9889 & 1.0064 \\
$\mathrm{~A} 7$ & 0.9800 & 0.9922 & 1.0045 & 0.9756 & 0.9791 & 0.9826 & 0.9826 & 1.0001 & 1.0177 \\
$\mathrm{~A} 8$ & 0.9793 & 0.9916 & 1.0039 & 0.9749 & 0.9784 & 0.9819 & 0.9819 & 0.9995 & 1.0170 \\
A9 & 0.9736 & 0.9859 & 0.9982 & 0.9692 & 0.9728 & 0.9763 & 0.9763 & 0.9938 & 1.0114 \\
A10 & 0.9528 & 0.9651 & 0.9774 & 0.9484 & 0.9519 & 0.9555 & 0.9555 & 0.9730 & 0.9905 \\
\hline
\end{tabular}


TABLE X

SENSITIVITY ANALYSIS WITH RESPECT TO CRITERION 7-9

\begin{tabular}{cccccccccc}
\hline & \multicolumn{3}{c}{$\mathbf{K}_{7}$} & \multicolumn{3}{c}{$\mathbf{K}_{8}$} & \multicolumn{3}{c}{$\mathbf{K}_{9}$} \\
\hline Alternative & $\mathrm{w}_{7}=0.1$ & $\mathrm{w}_{7}=0.3$ & $\mathrm{w}_{7}=0.5$ & $\mathrm{w}_{8}=0.1$ & $\mathrm{w}_{8}=0.3$ & $\mathrm{w}_{8}=0.5$ & $\mathrm{w}_{9}=0.1$ & $\mathrm{w}_{9}=0.3$ & $\mathrm{w}_{9}=0.5$ \\
\hline $\mathrm{A} 1$ & 0.9936 & 1.0111 & 1.0287 & 0.9910 & 1.0032 & 1.0155 & 0.9910 & 1.0032 & 1.0155 \\
$\mathrm{~A} 2$ & 0.9501 & 0.9676 & 0.9852 & 0.9474 & 0.9597 & 0.9720 & 0.9474 & 0.9597 & 0.9720 \\
$\mathrm{~A} 3$ & 0.9817 & 0.9993 & 1.0168 & 0.9791 & 0.9914 & 1.0037 & 0.9791 & 0.9914 & 1.0037 \\
$\mathrm{~A} 4$ & 0.9556 & 0.9731 & 0.9907 & 0.9529 & 0.9652 & 0.9775 & 0.9529 & 0.9652 & 0.9775 \\
$\mathrm{~A} 5$ & 0.9757 & 0.9933 & 1.0108 & 0.9731 & 0.9854 & 0.9977 & 0.9731 & 0.9854 & 0.9977 \\
$\mathrm{~A} 6$ & 0.9713 & 0.9889 & 1.0064 & 0.9687 & 0.9810 & 0.9933 & 0.9687 & 0.9810 & 0.9933 \\
$\mathrm{~A} 7$ & 0.9826 & 1.0001 & 1.0177 & 0.9800 & 0.9922 & 1.0045 & 0.9800 & 0.9922 & 1.0045 \\
$\mathrm{~A} 8$ & 0.9819 & 0.9995 & 1.0170 & 0.9793 & 0.9916 & 1.0039 & 0.9793 & 0.9916 & 1.0039 \\
$\mathrm{~A} 9$ & 0.9763 & 0.9938 & 1.0114 & 0.9736 & 0.9859 & 0.9982 & 0.9736 & 0.9859 & 0.9982 \\
$\mathrm{~A} 10$ & 0.9555 & 0.9730 & 0.9905 & 0.9528 & 0.9651 & 0.9774 & 0.9528 & 0.9651 & 0.9774 \\
\hline
\end{tabular}

TABLE XI

SENSITIVITY ANALYSIS WITH RESPECT TO CRITERION 10-12

\begin{tabular}{cccccccccc}
\hline & \multicolumn{3}{c}{$\mathbf{K}_{\mathbf{1 0}}$} & \multicolumn{3}{c}{$\mathbf{K}_{11}$} & & \multicolumn{3}{c}{$\mathbf{K}_{\mathbf{1 2}}$} \\
\hline Alternative & $\mathrm{w}_{10}=0.1$ & $\mathrm{w}_{10}=0.3$ & $\mathrm{w}_{10}=0.5$ & $\mathrm{w}_{11}=0.1$ & $\mathrm{w}_{11}=0.3$ & $\mathrm{w}_{11}=0.5$ & $\mathrm{w}_{12}=0.1$ & $\mathrm{w}_{12}=0.3$ & $\mathrm{w}_{12}=0.5$ \\
\hline $\mathrm{A} 1$ & 0.9910 & 1.0032 & 1.0155 & 0.9936 & 1.0111 & 1.0287 & 0.9910 & 1.0032 & 1.0155 \\
$\mathrm{~A} 2$ & 0.9474 & 0.9597 & 0.9720 & 0.9501 & 0.9676 & 0.9852 & 0.9474 & 0.9597 & 0.9720 \\
$\mathrm{~A} 3$ & 0.9791 & 0.9914 & 1.0037 & 0.9817 & 0.9993 & 1.0168 & 0.9791 & 0.9914 & 1.0037 \\
$\mathrm{~A} 4$ & 0.9529 & 0.9652 & 0.9775 & 0.9556 & 0.9731 & 0.9907 & 0.9529 & 0.9652 & 0.9775 \\
$\mathrm{~A} 5$ & 0.9731 & 0.9854 & 0.9977 & 0.9757 & 0.9933 & 1.0108 & 0.9731 & 0.9854 & 0.9977 \\
$\mathrm{~A} 6$ & 0.9687 & 0.9810 & 0.9933 & 0.9713 & 0.9889 & 1.0064 & 0.9687 & 0.9810 & 0.9933 \\
A7 & 0.9800 & 0.9922 & 1.0045 & 0.9826 & 1.0001 & 1.0177 & 0.9800 & 0.9922 & 1.0045 \\
A8 & 0.9793 & 0.9916 & 1.0039 & 0.9819 & 0.9995 & 1.0170 & 0.9793 & 0.9916 & 1.0039 \\
A9 & 0.9736 & 0.9859 & 0.9982 & 0.9763 & 0.9938 & 1.0114 & 0.9736 & 0.9859 & 0.9982 \\
A10 & 0.9528 & 0.9651 & 0.9774 & 0.9555 & 0.9730 & 0.9905 & 0.9528 & 0.9651 & 0.9774 \\
\hline
\end{tabular}

TABLE XII

SENSITIVITY ANALYSIS WITH RESPECT TO CRITERION 13-14

\begin{tabular}{ccccccc}
\hline & \multicolumn{3}{c}{$\mathbf{K}_{13}$} & \multicolumn{3}{c}{$\mathbf{K}_{14}$} \\
\hline Alternative & $\mathrm{W}_{13}=0.1$ & $\mathrm{w}_{13}=0.3$ & $\mathrm{w}_{13}=0.5$ & $\mathrm{w}_{14}=0.1$ & $\mathrm{w}_{14}=0.3$ & $\mathrm{w}_{14}=0.5$ \\
\hline A1 & 0.9910 & 1.0032 & 1.0155 & 0.9936 & 1.0111 & 1.0287 \\
$\mathrm{~A} 2$ & 0.9474 & 0.9597 & 0.9720 & 0.9501 & 0.9676 & 0.9852 \\
A3 & 0.9791 & 0.9914 & 1.0037 & 0.9817 & 0.9993 & 1.0168 \\
A4 & 0.9529 & 0.9652 & 0.9775 & 0.9556 & 0.9731 & 0.9907 \\
A5 & 0.9731 & 0.9854 & 0.9977 & 0.9757 & 0.9933 & 1.0108 \\
A6 & 0.9687 & 0.9810 & 0.9933 & 0.9713 & 0.9889 & 1.0064 \\
A7 & 0.9800 & 0.9922 & 1.0045 & 0.9826 & 1.0001 & 1.0177 \\
A8 & 0.9793 & 0.9916 & 1.0039 & 0.9819 & 0.9995 & 1.0170 \\
A9 & 0.9736 & 0.9859 & 0.9982 & 0.9763 & 0.9938 & 1.0114 \\
A10 & 0.9528 & 0.9651 & 0.9774 & 0.9555 & 0.9730 & 0.9905 \\
\hline
\end{tabular}




\section{CONCLUSION}

This study reveals that the BW and SAW methods can be used by the HR manager to evaluate the performance of contract employees and recommend the right contract employees for the extension of their work contracts. This research also contributes to the development of the BW method that is integrated with other MCDM methods where there is very little research that integrates the BW method with other MCDM methods so that it provides interesting opportunities for further research.

\section{REFERENCES}

[1] N. Smith, "Beyond Hiring and Firing: Human Resource Management?," medium.com, 2019. [Online]. Available: https://medium.com/. [Accessed: 28-Feb-2021].

[2] S. J. Sadjadi and M. Karimi, "Best-worst multi-criteria decision-making method: A robust approach," Decis. Sci. Lett., vol. 7, no. 4, pp. 323-340, 2018.

[3] N. Suhandi, Terttiaavini, and R. Gustriansyah, "Decision support system for subsidized housing selection based on best-worst method and simple additive weighting," Int. J. Adv. Trends Comput. Sci. Eng., vol. 9, no. 3, pp. 33843389, 2020.

[4] R. Gustriansyah, Ermatita, D. Palupi Rini, and R. Firsandaya Malik, "The Criteria That Have A Significant Effect on Forecasting the Number of Sales Using the Best-Worst Method," in 2020 International Conference on Informatics, Multimedia, Cyber and Information System (ICIMCIS), pp. 236-241, 2020.

[5] R. Gustriansyah, Ermatita, D. P. Rini, and R. F. Malik, "Integration of Decision-Making Method and DataMining Method as A Preliminary Study of Novel Sales Forecasting Method," Int. J. Adv. Trends Comput. Sci. Eng., vol. 9, no. 4, pp. 5730-5735, Aug. 2020.

[6] J. T. Simanullang, "Aplikasi Penilaian Karyawan Kontrak di BRI Menggunakan Metode AHP," Universitas Mercu Buana, 2019.

[7] R. Gustriansyah, D. I. Sensuse, and A. Ramadhan, "Decision support system for inventory management in pharmacy using fuzzy analytic hierarchy process and sequential pattern analysis approach," in $20153 \mathrm{rd}$ International Conference on New Media (CONMEDIA), pp. 1-6, 2015.

[8] S. Komariah Hildayanti et al., "Enterprise architecture framework selection for higher education using TOPSIS method," Int. J. Eng. Technol., vol. 7, no. 4, pp. 53275330, 2018.

[9] N. Ainun, "Sistem Pendukung Keputusan Menentukan Perpanjangan Kontrak Karyawan Berdasarkan Penilaian Kinerja pada PT. Indomas Makmur Jaya Menggunakan Metode Vikor," Pelilta Inform., vol. 8, no. 1, 2019.

[10] R. Gustriansyah, "Sistem Pendukung Keputusan Pemilihan Dosen Berprestasi dengan Metode ANP dan TOPSIS," in Seminar Nasional Teknologi Informasi dan
Komunikasi (SENTIKA), pp. 33-40, 2016.

[11] M. F. Bady, "Sistem Pendukung Keputusan Perpanjangan Kontrak Tenaga Kerja di PT. Metal Hitech Menggunakan Metode SAW," Universitas Muhammadiyah Gresik, 2017.

[12] A. K. Ardilies, "Sistem Pendukung Keputusan Penilaian Kinerja Karyawan Kontrak Menggunakan Metode Simple Additive Weighting," Universitas Teknokrat Indonesia, 2019.

[13] N. Azizah, S. Rahayu, and N. Adhista, "Perancangan Sistem Informasi Penilaian Kinerja Karyawan SPG Berstatus Kontrak pada PT. Softex Indonesia Menggunakan Metode Simple Additive Weighting (SAW)," SENSI J., vol. 3, no. 2, pp. 182-189, Aug. 2017.

[14] A. Wibowo, "Sistem Pendukung Keputusan Perpanjangan Masa Kerja Karyawan Kontrak Menggunakan Metode Simple Additive Weighting," Universitas Mercu Buana Yogyakarta, 2019.

[15] I. Permana, "Pengangkatan Karyawan Kontrak Menggunakan Metode Simple Additive Weight pada Sistem Informasi Manajemen Rekrutmen PT Surya Energi Indotama," Universitas Komputer Indonesia, 2019.

[16] A. Mulyana, "Implementasi Sistem Pendukung Keputusan untuk Menentukan Status Karyawan Kontrak Menjadi Karyawan Tetap Menggunakan Metode Simple Additive Weigheting (SAW) Berbasis Web pada PT. Dominos Pizza," Universitas Pamulang, 2017.

[17] P. Ayu, "Sistem Pendukung Keputusan dalam Penentuan Kelayakan Karyawan Kontrak Menjadi Karyawan Tetap pada PT. Inti Surya Menggunakan Metode Promethee," Universitas Potensi Utama, 2019.

[18] D. Saripurna, J. Halim, and Z. Lubis, "Sistem pendukung Keputusan Dalam Menetukan Kelayakan Karyawan Kontrak Menjadi Status Karyawan Tetap PT. ISS Indonesia dengan menggunakan Metode Multi Attribute Utility Theory," J. Teknol. Sist. Inf. dan Sist. Komput., vol. 1, no. 2, 2018.

[19] E. Prasetianto, "Sistem Pendukung Keputusan Perpanjangan Kontrak Tenaga Kerja Menggunakan Metode TOPSIS," Universitas Muhammadiyah Gresik, 2016.

[20] N. S. Fitry, M. Suhaidi, and E. Alimudin, "Sistem Pendukung Keputusan Penentuan Karyawan Kontrak Menjadi Karyawan Tetap Menggunakan Metode TOPSIS pada PT. Murini Samsam II Pelintung,” Sekolah Tinggi Teknologi Dumai, 2017.

[21] R. Tenggara, "Perancangan Sistem Penentuan Keputusan Karyawan Kontrak Menjadi Karyawan Tetap Menggunakan Metode TOPSIS pada PT. Super Tata Raya Steel," Universitas Buddhi Dharma, 2018.

[22] A. D. Kurniawan, "Sistem Pendukung Keputusan Seleksi Pengangkatan Karyawan Tetap dari Tenaga Kontrak di PT. Petrosida dengan Menggunakan Metode TOPSIS," 
Universitas Muhammadiyah Gresik, 2016.

[23] L. Chairani, "Penerapan Sistem Pendukung Keputusan Rekomendasi Status Pengangkatan Karyawan Kontrak Menjadi Tetap Menggunakan Metode TOPSIS (Studi Kasus: Matahari Department Store Lampung) Berbasis Web," Universitas Teknokrat Indonesi, 2018.

[24] F. Awai and L. Suryadi, "Pemilihan Karyawan Kontrak Menggunakan TOPSIS di TB. Gramedia Baywalk Pluit," Indones. J. Inf. Syst., vol. 3, no. 1, pp. 526-531, 2020.

[25] H. Maulana and P. K. Wardani, "Sistem Rekomendasi Kelanjutan Kontrak Karyawan Menggunakan Metode TOPSIS," MULTINETICS J. Multimed. Netw. Informatics, vol. 4, no. 1, pp. 14-20, 2018.

[26] Anharullah, "Sistem Pendukung Keputusan Pengangkatan Tenaga Kerja Kontrak Menjadi Karyawan Tetap Pada PDAM Tirta Tuah Benua Menggunakan Metode SMARTER Berbasis Web," STMIK Widya Cipta Dharma, 2021.

[27] S. B. Yanto, "Sistem Pendukung Keputusan Karyawan Kontrak Menjadi Karyawan Tetap Berdasarkan Rekomendasi Manajer pada Otoritas Jasa Keuangan Regional 3 Jawa Tengah dan DIY Menggunakan Metode SMART," Universitas Stikubank, 2020.

[28] E. B. S. F. Nugraha, "Sistem Pendukung Keputusan Untuk Menentukan Status Karyawan Kontrak Menjadi Karyawan Tetap Menggunakan Metode SMART," J. Sist. Inf. dan Teknol. Inf., vol. 7, no. 2, 2018.

[29] O. Alfina and M. Safii, "Analisa Kontrak Kerja Karyawan pada Perusahaan Ritail Modern Menggunakan Metode SMART," J. Manaj. Inform. dan Komputerisasi Akunt., vol. 3, no. 1, 2019.

[30] F. E. C. Ningrum, "Penilaian Kinerja Karyawan Kontrak Menggunakan Metode Rating Scale pada Personalia and General Affair Rumah Potong Ayam," Universitas Brawijaya, 2018.

[31] A. N. Husna, "Penilaian Kinerja Karyawan Kontrak
Departemen Fiber PT. Adiputro Wirasejati Menggunakan Metode Rating Scale," Universitas Brawijaya, 2019.

[32] Guswantoro, "Sistem Penilaian Karyawan Kontrak Menjadi Karyawan Tetap Menggunakan Metode Electre," Universitas Muhammadiyah Jember, 2018.

[33] R. Gustriansyah, N. Suhandi, and F. Antony, "The Design of UML-Based Sales Forecasting Application," Int. J. Recent Technol. Eng., vol. 7, no. 6, pp. 1507-1511, 2019.

[34] A. Sanmorino, R. Gustriansyah, Terttiaavini, and Isabella, "The Toolkit of Success Rate Calculation of Broiler Harvest," Telkomnika (Telecommunication, Comput. Electron. Control., vol. 15, no. 4, pp. 1952-1959, 2017.

[35] J. Rezaei, "Best-worst multi-criteria decision-making method: Some properties and a linear model," Omega, vol. 64, pp. 126-130, Oct. 2016.

[36] J. Rezaei, T. Nispeling, J. Sarkis, and L. Tavasszy, “A supplier selection life cycle approach integrating traditional and environmental criteria using the best worst method," J. Clean. Prod., vol. 135, pp. 577-588, 2016.

[37] J. Rezaei, "Best-Worst Multi-Criteria Decision-Making Method," Omega - Int. J. Manag. Sci., vol. 53, pp. 49-57, 2015.

[38] C. W. Churchman and R. L. Ackoff, "An Approximate Measure of Value," J. Oper. Res. Soc. Am., vol. 2, no. 2, pp. 172-187, May 1954.

[39] K. Palczewski and W. Sałabun, "The fuzzy TOPSIS applications in the last decade," Procedia Comput. Sci., vol. 159, pp. 2294-2303, 2019.

[40] C.-L. Hwang and K. Yoon, "Methods for multiple attribute decision making," in Multiple attribute decision making, vol. 1, Spinger-Verlag, pp. 58-191, 1981. 
JUITA: Jurnal Informatika e-ISSN: 2579-8901; Vol. 9, No. 2, November 2021 